\title{
УДОСКОНАЛЕННЯ КАДРОВОГО МЕНЕДЖМЕНТУ В ЗБРОЙНИХ СИЛАХ УКРАЇНИ В КОНТЕКСТІ РЕФОРМ ОБОРОННОЇ СФЕРИ
}

Плеханов Д. О., д-р наук з держ., упр., доцент, Інститут державного управління, Чорноморський національний університет імені Петра Могили, м. Миколаїв, Україна

Плеханова О. П., д-р наук з держ., упр., Чорноморський національний університет імені Петра Могили, м. Миколаїв, Україна

Стаття присвячена проблемам забезпечення якісним персоналом ЗСУ, формуванню нових механізмів залучення фахівиів до лав ЗСУ в контексті оборонної, кадрової та інших реформ, з урахуванням сучасних міжнародних та військових факторів, які впливають на формування дієздатної армії України. Основна увага зосереджена на формуванні комплексної Концепиії кадрової політики в ЗСУ. В статті акцентовано увагу на тому, що на вітчизняному ринку прачі тривалий час формувалася дуже низька конкурентоспроможність військової сфери внаслідок недостатнього грошового забезпечення військових, недосконалої системи сочіальних гарантій, наявності серйозних житлових проблем та відсутності впевненості щзодо перспектив професійного та кар'єрного зростання, щуо в кінцевому випадку призвело до дестабілізації ситуації у Збройних Силах України та відпливу з них найбільш досвідчених та підготовлених військових фахівців за кордон або в інші сфери життєдіяльності суспільства.

Авторами зроблено висновок про те, щчо подальших досліджень потребують визначення термінів та понять, якими має бути доповнена Концепція кадрової політики в ЗСУ, приділена належна увага методам та технологіям кадрового менеджменту.

Ключові слова: кадрова політика; кадровий менеджмент; Збройні Сили Украӥни; військова служба; реформування обороноздатності.

Постановка проблеми у загальному вигляді. Формування військової кадрової політики України відбувається в період но- 
вих форм військових конфліктів, «гібридних війн», трансформації способів ведення бойових дій, інформаційних війн, політичними ускладненнями євроінтеграційного процесу України тощо.

Одним із ключових напрямів оборонної реформи $є$ кадровий менеджмент щодо особового складу ЗСУ. Наприклад, у 2014 році керівний склад ЗСУ зіткнувся 3 вагомою всеосяжною проблемою відсутності військово-навчених людських ресурсів військовозобов'язаних для комплектування посад, передбачених штатами воєнного часу, i, навіть, збільшення їх чисельності до 250 осіб значно не покращило ситуацію [4]. Основними причинами зменшення кількості підготовленого мобілізаційний ресурсу країни стало скорочення чисельності ЗС України та перехід на контрактний принцип комплектування. Отже, чисельність військовослужбовців строкової служби постійно зменшувалась, і все менше громадян України здобували військовооблікову спеціальність під час проходження строкової військової служби та набували практичних навичок і умінь, необхідних для збройного захисту держави. I це лише один з аспектів, що потребує реформування.

Проблема ефективного кадрового менеджменту в Збройних Силах України є дуже актуальною. Управління кадровими процесами здійснюється не завжди послідовно через брак відповідного науково-методичного та аналітичного забезпечення. Потребує удосконалення нормативно-правове забезпечення в галузі військової кадрової політики, оскільки цей напрям визначає ефективність механізмів реалізації оборонних реформ в Україні загалом. Виникає необхідність розробки дієвих механізмів реалізації кадрової політики на державному рівні та, зокрема, в системі Збройних Сил України. Актуальність обраної теми дослідження зумовлена також прагненням України відповідати міжнародним стандартам НАТО та сучасної військової сфери, що неможливо без вироблення нових підходів щодо роботи з управління персоналом.

Аналіз останніх досліджень і публікацій. Розгляду проблем розвитку системи управління персоналом та державної кадрової політики присвячені праці зарубіжних і вітчизняних фахівців: М. Армстронга, М. Альберта, Г. Бекера, К. Вайса, Е. Ведунга, а 
також В. Андрушка, В. Бакуменка, М. Білинської, О. Боровського, Н.Гончарук, Н. Грицяк, С. Дубенко, В. Князєва, О. Крушельницької, В. Лугового, А. Михненка, Н. Нижник, Т. Пахомової, А. Рачинського, І. Розпутенка, С. Серьогіна, В. Трощинського та ін.

Переосмислення вітчизняними фахівцями проблем кадрового менеджменту в Україні дозволило обгрунтувати рекомендації та шляхи подальшого розвитку державної кадрової політики, водночас специфіка кадрового менеджменту саме в ЗСУ характеризується відсутністю комплексних досліджень, i, як наслідок, практичних механізмів реалізації кадрової політики в системі ЗСУ. Наукові розробки О. Їжака, В. Жаховського, О. Сивака, Г. Тихонова, О. Шевцова, В. Шеховцова 3 проблематики реалізації кадрової політики в Збройних Силах України торкалися окремих її складових (кадрового забезпечення військової медицини та освіти, контрактної служби, зарубіжного досвіду). А.Медвідь в своїх дослідженнях на основі системного підходу обгрунтовує основні засади кадрової політики в ЗСУ [3, с. 224]. Водночас нові умови трансформації військової сфери, прийняті останнім часом нормативно-правові документи щодо підвищення обороноздатності країни зумовлюють вироблення нових підходів до системи кадрового забезпечення та менеджменту в ЗСУ.

Формулювання цілей статті. Метою статті є обгрунтування напрямів удосконалення кадрового менеджменту в ЗСУ в контексті реформ оборонної сфери.

Виклад основного матеріалу дослідження. Умови, в яких відбувається формування та модернізація української армії, вимагають реформ нового типу - за браком часу та ресурсів, необхідно якнайшвидше обирати оптимальні методи та механізми державного управління обороноздатністю країни, що водночас $є$ унікальним досвідом для нашої держави. Основним показником обороноздатності країни та ефективності державного управління у військовій сфері $є$ спроможність особового складу Збройних Сил України виконувати покладені на нього завдання. Анексія Криму російськими військами у 2014 році, бойові дії на Сході України продемонстрували неготовність Збройних Сил України реагувати на виниклі загрози територіальній цілісності держави. 
Протягом 2014-2017 років була проведена масштабна робота щодо підвищення обороноздатності країни. Як зазначив Президент України у своєму виступі під час складання Військової присяги молодим поповненням Окремого полку Президента України та 101-ї окремої бригади охорони Генерального штабу ЗСУ 9 травня 2017 року, сучасна українська армія дуже сильно відрізняється від тієї, яка була у 2014 році [1].

Оцінка стану воєнної безпеки держави, а також набутий досвід участі ЗСУ в антитерористичній операції, виявили низку проблем функціонування сил оборони в умовах існуючих та потенційних загроз, що дозволило визначити напрями, мету та механізми оборонної реформи в Україні. Таким чином, метою оборонної реформи $є$ розвиток (відповідно до євроатлантичних норм та критеріїв членства в НАТО) спроможностей Міністерства оборони України, Збройних Сил України та інших складових сил оборони, необхідних для адекватного реагування на загрози національній безпеці у воєнній сфері, захисту України, їі суверенітету, територіальної цілісності та непорушності (недоторканності) кордонів, підтримки міжнародного миру та безпеки [10].

Серед основних документів, які складають правову основу кадрового менеджменту у військовій сфері та визначають напрями його реформування, слід відзначити Конституцію України та закони України, Стратегію національної безпеки України, яка затверджена указом Президента України від 26 травня 2015 року № 287 [6], Воєнну доктрину України, затверджену указом Президента України від 24 вересня 2015 року № 555 [7], Концепцію розвитку сектору безпеки і оборони України, затверджену указом Президента України від 14 березня 2016 року № 92 [8], Стратегічний оборонний бюлетень України (далі - Стратегічний бюлетень), затверджений указом Президента України від 06 червня 2016 року № 240/2016 [9], а також міжнародні договори України.

Стратегічний бюлетень спрямований на забезпечення практичної реалізації положень Воєнної доктрини України та Концепції розвитку сектору безпеки і оборони України, визначає стратегічні й оперативні цілі оборонної реформи та очікувані результати їх до- 
сягнення з урахуванням актуальних воєнно-політичних загроз та викликів [9].

Метою проведення оборонної реформи в Україні $є$ набуття та підтримання силами оборони необхідного рівня бойової готовності та здатності до виконання завдань оборони держави (оборонних спроможностей), ефективного реагування на виникаючі воєнні загрози та воєнно-політичні виклики національній безпеці, підвищення рівня оперативної сумісності Збройних Сил України та інших військових формувань 3 підрозділами збройних сил держав-членів НАТО та СС до виконання спільних завдань в міжнародних операціях із підтримання миру і безпеки [10].

Для досягнення мети оборонної реформи визначаються такі пріоритетні цілі з урахуванням актуальних та прогнозованих ресурсних обмежень [9]:

1. Об'єднане керівництво силами оборони, що здійснюється відповідно до принципів і стандартів, прийнятих державами-членами НАТО;

2. Ефективна політика системи планування і управління ресурсами в секторі оборони з використанням сучасних євроатлантичних підходів;

3. Оперативні (бойові, спеціальні) спроможності сил оборони, необхідні для гарантованої відсічі збройній агресії, оборони держави, підтримання миру та міжнародної безпеки;

4. Об'єднана система логістики і система медичного забезпечення, здатні надати підтримку всім компонентам сил оборони;

5. Професіоналізація сил оборони та створення необхідного військового резерву.

Таким чином, кожен 3 пріоритетів оборонної політики безпосередньо пов'язаний з формуванням відповідного кадрового потенціалу, механізмами залучення високопрофесійних службовців як на вищому рівні, так й інших ланках ЗСУ, стосується різних аспектів управління людськими ресурсами у військовій сфері. Але 3 викладеного можна побачити, що трансформація системи кадрового менеджменту в ЗСУ виділена в окремий пріоритет - професіоналізацію сил оброни та створення необхідного військового резерву. 
Цей пріоритет є не тільки необхідною умовою для формування якісного кадрового потенціалу Збройних Сил України, інших складових сил оборони, комплектування їх підготовленим та мотивованим особовим складом, а й однією з вимог відповідності військової сфери критеріям та показникам НАТО [10].

В результаті реалізації пріоритету планується, що в Україні буде сформовано необхідний кадровий потенціал Збройних Сил та інших складових сил оборони професійно підготовленими, з високими морально-діловими якостями військовослужбовцями, здатними якісно вирішувати складні військово-професійні завдання у мирний час та особливий період; сили оборони будуть укомплектовані підготовленим та мотивованим особовим складом; буде створено та підготовлено стратегічний резерв Збройних Сил України, здатний здійснювати наступальні (контрнаступальні) дії, посилювати угруповання військ (сил) на загрозливих напрямах, забезпечувати ротацію військ (сил), ïх поповнення та заміну на випадок втрати боєздатності.

В Стратегічному бюлетені визначені основні чотири оперативні цілі для досягнення пріоритету [9]:

- розвиток соціально-гуманітарного забезпечення персоналу;

- удосконалення системи військової освіти та підготовки кадрів;

- реформування системи мобілізації та створення військового резерву;

- створення сучасної системи кадрового менеджменту.

В результаті реалізації зазначених цілей планується, що буде змінено образ мислення особового складу в напрямі європейських цінностей; рівень матеріального та інших видів забезпечення військовослужбовців приведено у відповідність з умовами проходження служби; система військової освіти має набути практичного спрямування навчання, впроваджено в навчальний процес передові методики підготовки збройних сил держав-членів НАТО, а також технології дистанційного навчання, військові навчальні заклади повинні бути забезпечені сучасними і перспективними зразками озброєння та військової техніки; державна система мобілізації та мобілізаційної підготовки повинна діяти на основі базових європейських 
підходів; має бути сформований військовий резерв, створено Сдиний державний реєстр військовозобов'язаних для забезпечення військового обліку громадян України, забезпечено ефективне функціонування системи підготовки резервістів та військовозобов'язаних; впроваджено раціональне співвідношення категорій особового складу сил оборони, створено ефективну систему управління кар'єрою військовослужбовців, забезпечено прозору та доброчесну систему добору, розстановки та призначення особового складу на посади.

Ці норми не лише якісно змінюють систему кадрового забезпечення та кадрової політики в ЗСУ, також вони тісно пов'язані із тими змінами, які зараз відбуваються в НАТО [10].

На основі Стратегічного бюлетеня розробляються та реалізуються Державна програма розвитку Збройних Сил України, державні програми розвитку інших складових сил оборони в частині залучення їх до виконання завдань оборони держави, які є підставою для розроблення відповідних планів утримання та розвитку складових сил оборони; державні цільові оборонні програми, спрямовані на створення нових та модернізацію існуючих систем, комплексів і зразків озброєння та військової техніки, будівництво важливих військових об'єктів, розв'язання інших проблем у сфері оборони.

Водночас, аналіз нормативно-правової бази дозволяє зробити висновки про відсутність єдиного системного нормативно-правового документу щодо кадрового менеджменту в ЗСУ. Концепція кадрової політики у Збройних Силах України на період до 2017 року, яка була затверджена Наказом Міноборони України від 01.12.2013 № 843 [2], втратила свою актуальність та існує нагальна потреба в розробленні нової відповідної Концепції на основі та з урахуванням вищезазначених нормативно-правових актів, що визначають реформування у військовій сфері.

В оновленій Концепції необхідно приділити увагу аспектам, які $\epsilon$ найбільш проблемними в кадровому менеджменті ЗСУ.

Як зазначає А. Медвідь, недоліком системи кадрового менеджменту в Збройних Силах України є те, що вона розрахована на функціонування за номенклатурним принципом («жорстка вертикаль»), який передбачає велику кількість людських ресурсів в умовах ве- 
дення повномасштабних бойових (воєнних) дій, структура ії органів управління не дає змоги повноцінно застосовувати індивідуальний підхід у роботі з персоналом та оперативно приймати кадрові рішення як по горизонталі, так і по вертикалі [5, с. 7-8].

Удосконалення кадрової політики в Збройних Силах України та механізмів іiі реалізації зумовлене необхідністю забезпечення здатності особового складу Збройних Сил до виконання нових завдань в умовах змін форм, методів і засобів ведення бойових дій; реалізації Україною політичного рішення щодо наближення рівня розвитку Збройних Сил до стандартів країн-членів НАТО; участі в АТО та миротворчих операціях; упровадження демократичного цивільного контролю в Збройних Силах, підвищення ролі цивільного сектору в управлінні Збройними Силами, а також відсотка цивільних посад в органах військового управління Збройних Сил; інтеграції системи військової освіти до державної системи освіти, а також оптимізації мережі вищих військових навчальних закладів [10].

Спостерігається необхідність в удосконаленні як самої системи ЗСУ, військових кадрових служб, так і керівної ланки. При цьому важливим є підготовка фахівців для кадрових служб в ЗСУ, розробка нових навчальних курсів 3 підвищення кваліфікації та перекваліфікації військовослужбовців. Іншим напрямком є запровадження системи підвищення кваліфікації військовослужбовців для проходження служби відповідно до нових умов та міжнародних, особливо європейських стандартів в кожній з галузей військової сфери.

Кожна країна світу має власні, притаманні лише їй механізми реалізації кадрової політики у військовому середовищі. Ефективність реалізації кадрової політики залежить від фінансових можливостей держави, престижу військової служби в країні, їі ролі й місця в суспільстві та конкурентоспроможності Збройних Сил на ринку праці держави, що забезпечує можливість підготовки кращих фахівців.

Впровадження прийнятих реформ є складним та високовитратним процесом, оскільки військова сфера завжди була і $є$ однією 3 важливих статей бюджету будь-якої держави. Заходи, які спрямовані на досягнення цілей оборонної реформи, повинні забезпечувати- 
ся у межах видатків, визначених Законом України про Державний бюджет України на відповідний рік, а також можуть фінансуватися додатково за рахунок благодійних внесків фізичних та юридичних осіб у порядку, визначеному Кабінетом Міністрів України, та з інших джерел, не заборонених законодавством.

Положеннями Стратегії національної безпеки України та Воєнної доктрини України передбачено щорічно спрямовувати на бюджетне фінансування сектору безпеки і оборони не менше 5 відсотків запланованого обсягу валового внутрішнього продукту, у тому числі на оборону - не менше 3 відсотків запланованого обсягу валового внутрішнього продукту [6; 7]. Обсяг фінансування між складовими сил оборони визначається Законом про Державний бюджет України на відповідний рік залежно від їх функцій, завдань та відповідальності у сфері безпеки й оборони. Тобто у військовій сфері $є$ певна частка надходжень та фінансового забезпечення, яка повинна бути спрямована на кадрову політику та ії удосконалення.

На вітчизняному ринку праці тривалий час формувалася дуже низька конкурентоспроможність військової сфери внаслідок недостатнього грошового забезпечення військових, недосконалої системи соціальних гарантій, наявності серйозних житлових проблем та відсутності впевненості щодо перспектив професійного та кар'єрного зростання, що в кінцевому випадку призвело до дестабілізації ситуації в Збройних Силах України та відпливу з них найбільш досвідчених та підготовлених військових фахівців за кордон або в інші сфери життєдіяльності суспільства.

Висновки. На основі проведеного аналізу можна визначити такі елементи розвитку системи кадрового менеджменту в ЗСУ, як: реформи в системі кадрового менеджменту та запровадження нових форм, методів та механізмів реалізації кадрової політики; удосконалення методів та форм залучення на військову службу України; запровадження кадрового військового резерву; розробка системи підготовки кадрів у відповідності до основних нормативно-правових актів у військовій сфері; оптимізація соціального та гуманітарного забезпечення персоналу, адаптація військовослужбовців до цивільного життя. 
Серед напрямів удосконалення кадрового менеджменту в ЗСУ доцільно виділити наступні: підготовка фахівців для кадрових служб ЗСУ на основі нових стандартів залучення, адаптації, проходження військової служби; запровадження кадрових технологій у відповідності до стандартів НАТО, приведення їх до світового рівня з метою подальшої інтеграції військової сфери України в єдиний європейський сектор безпеки; оптимізація механізмів державного управління військовою сферою та побудова на цих принципах кадрової політики в ЗСУ; удосконалення нормативно-правового забезпечення в галузі кадрової політики як на державному рівні, так і на рівні Міністерства оборони України - прийняття відповідної Концепції; належне фінансування потреб Збройних Сил України; розвиток соціального та ресурсного забезпечення військового відомства на рівні світових стандартів; розроблення оптимальної структури та визначення чисельності Збройних Сил України відповідно до потенційних можливостей держави, що визначатиме кадрову політику у військовій сфері та розміщення державного замовлення на підготовку військових спеціалістів.

Подальших досліджень потребують визначення термінів та понять, якими має бути доповнена Концепція кадрової політики в 3СУ, приділена належна увага методам та технологіям кадрового менеджменту, які будуть застосовуватися в майбутньому при адаптації, вступі, мобілізації, проходженні військової служби у відповідності до міжнародних військових стандартів, зарубіжний досвід кадрового менеджменту у військовій сфері, а саме в СС, НАТО та ін.

\section{Стаття надійшла до редакції: 10.11.2018}




\section{IMPROVEMENT OF THE PERSONNEL MANAGEMENT IN THE ARMED FORCES OF UKRAINE IN THE CONTEXT OF DEFENSE REFORMS}

Dmytro Plekhanov, Doctor of Public Administration, Associate Professor, of Petro Mohyla Black Sea National University, Mykolaiv, Ukraine

Oksana Plekhanova, Doctor of Public Administration, of Petro Mohyla Black Sea National University, Mykolaiv, Ukraine

The article is deals with the problems of the ensuring high-quality personnel of the Armed Forces, forming new mechanisms for attracting specialists to the Armed Forces in the context of defense, personnel and other reforms, taking into account the current international and military factors that influence on the formation of a capable army of Ukraine. The main attention is paid to the formation of an integrated Concept of personnel policy in the Armed Forces of Ukraine.

The elements of the personnel management system development in the ZSU are determined, namely: reforms in the personnel management system and the introduction of new forms, methods and mechanisms for the implementation of personnel policy; improvement of methods and forms of involvement in the military service of Ukraine; introduction of a personnel reserve of military personnel; development of the personnel training system in accordance with the basic legal acts in the military sphere; optimization of social and humanitarian provision of personnel, adaptation of servicemen to civilian life.

The following directions of improvement of personnel management in the Armed Forces of Ukraine are highlighted: preparation of specialists for personnel services of the Armed Forces on the basis of new standards of attraction, adaptation, military service; introduction of personnel technologies in accordance with NATO standards, bringing them to the world level in order to further integrate the military sphere of Ukraine into a single European security sector; optimization of mechanisms of state management of the military sphere and building on these principles personnel policy in the Armed Forces; Improvement of normative and 
legal provision in the field of personnel policy both at the state level and at the level of the Ministry of Defense of Ukraine - adoption of the relevant Concept; proper financing of the needs of the Armed Forces of Ukraine; development of social and resource support of the military department at the level of world standards; the development of an optimal structure and determination of the size of the Armed Forces of Ukraine in accordance with the potential capabilities of the state, which will determine the personnel policy in the military sphere and the placement of a state order for the training of military specialists.

Keywords: personnel policy, personnel management, the Armed Forces of Ukraine, military service, defense capacity reform.

\section{Received: 10.11.2018}

\section{References:}

1. The President of Ukraine, «Speech of the President of Ukraine, Supreme Commander-in-Chief of the Armed Forces of Ukraine during the drawing up of the Military Oath by the young replenishment of the Separate Regiment of the President of Ukraine and the 101st Special Defense Brigade of the General Headquarters of the Armed Forces, May 9, 2017», www.president. gov.ua Retrieved from http://www.president.gov.ua/news/vistup-prezidentaverhovnogo-golovnokomanduvacha-zbrojnih-si-41278 [in Ukrainian].

2. The Ministry of Defense of Ukraine (2013), «Order «Concept of personnel policy in the Armed Forces of Ukraine for the period until 2017»» mil.gov.ua Retrieved from http://www.mil.gov.ua/diyalnist/kadrova-politika/ konczepcziya-kadrovoi-politiki-v-zbrojnih-silah-ukraini/ [in Ukrainian].

3. Medvid, A.P. and Zakharov, O.B. (2011) «The personnel policy in the Armed Forces of Ukraine as the system of the personnel management», Visnik Nacionalnogo universitetu oborony Ukrainy : zb.nauk.pr., vol.3(22), pp.220224. [in Ukrainian].

4. The Verkhovna Rada of Ukraine (2015), The Law of Ukraine "About the quantity of the Armed Forces of Ukraine", zakon0.rada.gov.ua Retrieved from http://zakon0.rada.gov.ua/laws/show/235-19 [in Ukrainian].

5. Medvid, A.P. and Polovinkyn, I.M. (2010), Systema kadrovogo menegmentu u Zbroynyh Sylah Ukrainy : osoblivosti rozvitku [The system 
of the personnel management in the Armed Forces of Ukraine: peculiarities of development], AGU ZS, Kyiv, Ukraine [in Ukrainian].

6. The President of Ukraine (2015) «Decree «About the decision of the National Security and Defense Council of Ukraine «About the National Security Strategy», zakon3.rada.gov.ua Retrieved from http://zakon3.rada.gov.ua/laws/ show/287/2015 // [in Ukrainian].

7. The President of Ukraine (2015) «Decree «About the decision of the National Security and Defense Council of Ukraine «About the new edition of the Military Doctrine of Ukraine», www.president.gov.ua Retrieved from http:// www.president.gov.ua/documents/5552015-19443 [in Ukrainian].

8. The President of Ukraine (2016) «Decree About the decision of the National Security and Defense Council of Ukraine «About the Concept of Development of the Security and Defense Sector of Ukraine», zakon2.rada.gov. ua Retrieved from http://zakon2.rada.gov.ua/laws/show/92/2016 [in Ukrainian].

9. The President of Ukraine (2016) «Decree About the decision of the National Security and Defense Council of Ukraine» "About the Strategic Defense Bulletin of Ukraine», www.president.gov.ua Retrieved from http:// www.president.gov.ua/documents/2402016-20137 [in Ukrainian].

10. The Official site of North Atlantic Treaty Organization (2015), "NATOUkraine Joint Working Group about Defence Reform", www.nato.int Retrieved from http://www.nato.int/cps/en/natohq/topics_50320.htm [in English]. 


\section{Відомості про авторів / Information about the Authors}

Плеханов Дмитро Олександрович: Чорноморський національний університет імені Петра Могили: вул. 68 Десантників 10, Миколаїв, 54003, Україна

E-mail: d_plehanov@ukr.net

\section{ORCID.ORG/0000-0002-2882-0073}

Dmytro Plekhanov: Petro Mohyla Black Sea National University: 68 Desantnykiv str. 10, Mykolaiv, 54003, Ukraine.

Плеханова Оксана Петрівна: Чорноморський національний університет імені Петра Могили: вул. 68 Десантників 10, Миколаїв, 54003, Україна

Oksana Plekhanova: Petro Mohyla Black Sea National University: 68 Desantnykiv str. 10, Mykolaiv, 54003, Ukraine.

E-mail: d_plehanov@ukr.net 